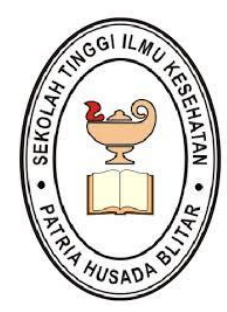

\title{
JNK
}

JURNAL NERS DAN KEBIDANAN (JOURNALOFNERS AND MIDWIFERY) http://jnk.phb.ac.id/index.php/jnk

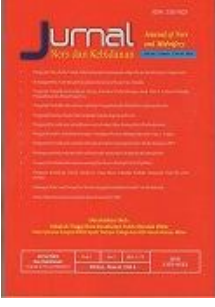

\section{The Effect of Health Promotion in Improving the Attitudes of Health Students in Carrying Out the Health Protocol to Prevent Covid-19}

\author{
Sarma Eko Natalia Sinaga
}

Nursing Department, Akademi Keperawatan Yatna Yuana Lebak, Indonesia

\begin{tabular}{l}
\hline Article Information \\
\hline History Article: \\
Received, 08/04/2021 \\
Accepted, 12/07/2021 \\
Published, 05/08/2021 \\
Keywords: \\
Consist Attitudes, Covid-19, Health \\
Protocols
\end{tabular}

\begin{abstract}
The Covid-19 health protocol is a rule or provision made for everyone to be obeyed in order to be able to carry out activities safely during the Covid-19 pandemic. The purpose of this research was to determine the effect of health promotion in improving the attitudes of health students in carrying out health protocols to prevent (Covid-19). The type of research was pre-experimental with a one group pre test and test design, and was carried out in October December 2020 at AKPER Yatna Yuana Lebak. The sample is all students AKPER Yatna Yuana Lebak, totaling 166 people. The research instrument used was a questionnaire distributed via google form, and the analysis of this research was univariate to see the description of the distribution of respondents before and after the intervention, while the bivariate analysis used the Pair T Test. The frequency distribution of the attitude variable had an overall increase before and after the intervention, while the largest increase occurred in the variable avoiding contact with family and people at home before bathing or changing clothes after doing activities outside the house, which was $3.62 \%$. In the statistical test, the p-valu was 0.017 which stated that there was a significant difference between the attitude before and after the intervention. After the health promotion regarding the prevention and control of Covid-19 was given, it was hoped that health students will be able to practice health protocols such as wearing mask, washing hands with soap, carrying out etiquette coughing/sneezing, bathing and changing clothes after activities outside the house, keeping distance from other people, avoiding frequent touching eyes, mouth and nose, checking their health if they feel fever. These all are in order to make them and their family can stay protected from Covid-19 and they can be the example for the surrounding community in implementing health protocols.
\end{abstract}

(C) 2021 Journal of Ners and Midwifery

Correspondence Address:

Akademi Keperawatan Yatna Yuana Lebak - Banten, Indonesia

P-ISSN : 2355-052X

Email: ekosarma171@gmail.com

E-ISSN : 2548-3811

DOI: 10.26699/jnk.v8i2.ART.p178-183

This is an Open Access article under the CC BY-SA license (http://creativecommons.org/licenses/by-sa/4.0/) 


\section{INTRODUCTION}

Coronavirus can cause disease in humans and animals. This virus causes respiratory tract disease in humans through respiratory infections, symptoms ranging from mild flu to serious illnesses such as Middle East Respiratory Syndrome (MERS) and Severe Acute Respiratory Syndrome (SARS). Spread among humans through droplets when coughing and sneezing (CDC, 2020). This virus can survive three hours in an aerosol, three days with plastic and stainless steel SARS CoV-2 (Gorbalenya et al., 2020).

On December 31, 2019 in Wuhan City, China, WHO reported a case of pneumonia with unknown cause. The pneumonia case was identified on January 7,2020, where the cause was the latest type of coronavirus (novel coronavirus). In early 2020 the NCP began to become a health problem in several countries outside the PRC and became a global pandemic. According to WHO, a cluster of pneumonia cases in Wuhan City whose causes are not clear is a global health problemThe number of this pandemic continues to grow and finally the cause is known, namely the Novel Coronavirus, news of deaths and new cases outside of China are also obtained._Covid 19 has been designated as a Public Health Emergency of International Concern (PHEIC) dated January 30, 2020) by WHO (Patel et al., 2020).

The spread and addition of Covid-19 cases occurred rapidly outside of Wuhan and other countries. On February 16, 2020, there were 51,857 confirmed cases of Covid-19 and 1,669 cases of death (CFR 3.2\%) in 25 countries (Tim Kerja Kementrian Dalam Negeri, 2020).

The first Covid-19 case in Indonesia was reported on March 2, 2020 and these cases continue to grow from day to day. On 9 July 2020 the Covid19 cases increased from the previous day and the confirmed cases of Covid-19 were 70,736 cases while the death cases were 3,417 cases (CFR 4.6\%) (Kementerian Kesehatan RI, 2020).

All countties affected by the covid-19 virus are experiencing difficult economic situations. The number of workplace and business closures decreased from $81 \%$ to $68 \%$. In America, employees lost $12.4 \%$ working hours while Europe and Central Asia $11.8 \%$ (IMF, 2020)

The bad effects of Covid-19 will continue as long as this case is still there. By carrying out health protocols in preventing and controlling Covid-19, it can reduce the incidence of Covid-19 cases. According to WHO, the health protocols that can prevent and control Covid-19 are washing hands with soap, wearing masks, not touching your face, covering your mouth when coughing or sneezing, if you are sick you are expected to stay at home, maintain cleanliness and maintain a minimum distance from other meter (WHO, 2020).

The increase of positive cases indicate that the transmission of the COVID-19 virus is still occurring due to the fact that health protocols are still being violated. It takes a change in behavior and attitude in its application and everyone is expected to get used to to all of it (BNPB, 2020).

According to Allport (1935), attitudes have a driving force (motivation), have a tendency to think, perceive and act. Attitude is a concept of the sociopsychological component, which has a tendency to act and perceive. And it is the readiness of the nervous system (neural setting) before giving a real response. One of the efforts made to change attitudes in implementing health protocols is through health promotion activities. Health promotion is the planned change of living conditions/lifestyle through the environment and individual habits to improve health (Hulu et al., 2020)

The sample of the research is health students who will be at the forefront of providing health services, and must follow the current trend issues of health problems, the researcher found that they still have less supportive attitude in implementing health protocols such as lack of desire to use mask when leaving the house, forget to wash their hands with soap and many of them do not do physical distancing behavior. But by providing education about health protocols, it is possible to reduce Covid-19 disease and support government programs to prevent the spread of Covid-19, as well as provide understanding or education to the public based on data through the media (Driposwana Putra et al., 2021; Syadidurrahmah, Muntahaya, Islamiyah, Fitriani, \& Nisa, 2020).

Based on the description above, the researcher felt education about the prevention and control of Coronavirus Disease (Covid-19) in health students is needed. Therefore, researcher is interested in knowing the influence of health promotion interventions in increasing attitudes to implementing health protocols to prevent Covid-19. 


\section{METHOD}

\section{Types of research}

This research type was a pre experimental with one group pre test and test design. The measurement design was carried out twice, the first measurement (pretest) was carried out before the treatment and the second measurement (post test) was carried out after the treatment was given or after the intervention. The health promotion intervention was carried out to all AKPER Yatna Yuana Lebak students simultaneously by providing education on materials for the prevention and transmission of Covid-19 using Windows 365 (Teams). Continued on the same day, it was conducted a simulation by demonstrating how to wash hands with soap, remove masks and maintain distance.

\section{Location and Time of Research}

The research was conducted in October December 2020 at AKPER Yatna Yuana Lebak.

\section{Population and Sample}

The population of the research was all active students of AKPER Yatna Yuana Lebak totaling 170 people. The sampling technique used total sampling. The respondents in this research were all stu- dents of AKPER Yatna Yuana Lebak, totaling 166 people, who met the inclusion criteria; all AKPER Yatna Yuana Lebak students who were still active, and willing to be research subjects and respondents. The exclusion criteria were students who were sick and unwilling to become research subjects and respondents.

\section{Data collection}

The research instrument used a questionnaire made by the researcher and its validity and reliability had been tested. The questionnaires were distributed via Google Form before and after the intervention and filled in by the respondents themselves.

\section{Processing and data analysis}

The type of analysis in this research is univariate to see the description of the distribution of respondents before and after the intervention, while the bivariate analysis uses a parametric statistical test The analysis was carried out to see the difference in the results of the initial measurement of the attitude variable before the intervention with the final measurement of the attitude variable after the intervention, namely by using the Pair T Test.

Table 1. Mean Attitude Variable in Implementing Health Protocol

\begin{tabular}{|c|c|c|c|c|}
\hline \multirow{2}{*}{ Attitude } & \multirow{2}{*}{$\mathbf{N}$} & \multirow{2}{*}{$\begin{array}{c}\text { Mean } \\
\text { Pre-Test }\end{array}$} & \multirow{2}{*}{$\frac{\text { Mean }}{\text { Post-Test }}$} & \multirow{2}{*}{ Enhancement \% } \\
\hline & & & & \\
\hline $\begin{array}{l}\text { 1. Covering mouth with tissue or inside of the } \\
\text { elbow when coughing or sneezing can prevent the } \\
\text { spread of the corona virus. }\end{array}$ & 166 & 3.69 & 3.79 & 2.71 \\
\hline $\begin{array}{l}\text { 2. If you have fever, cough and difficulty breathing, } \\
\text { immediately take medication and have a health check. }\end{array}$ & 166 & 3.77 & 3.83 & 1.59 \\
\hline $\begin{array}{l}\text { 3. To prevent the spread of the corona virus, you should } \\
\text { avoid touching eyes, mouth and nose too often. }\end{array}$ & 166 & 3.63 & 3.67 & 1.10 \\
\hline $\begin{array}{l}\text { 4. Avoid contact with family and people at home before } \\
\text { bathing or changing clothes after activities outside } \\
\text { the house. }\end{array}$ & 166 & 3.59 & 3.72 & 3.62 \\
\hline $\begin{array}{l}\text { 5. We recommend that you always leave the house using } \\
\text { a mask. }\end{array}$ & 166 & 3.81 & 3.90 & 2.36 \\
\hline $\begin{array}{l}\text { 6. We recommend that you limit the guests who come to } \\
\text { visit the house. }\end{array}$ & 166 & 3.51 & 3.58 & 1.99 \\
\hline $\begin{array}{l}\text { 7. Wash your hands using soap or an alcohol-based } \\
\text { hand wash before and after taking any action. }\end{array}$ & 166 & 3.70 & 3.77 & 1.89 \\
\hline
\end{tabular}




\section{RESULTS}

\section{Univariate Analysis}

From Table 1 it can be seen that there has been increase in attitudes in all tables. The biggest increase occurred in the variable avoiding contact with family and people at home before bathing or changing clothes after doing activities outside the house, which was $3.62 \%$. While the lowest increase in attitude variables was in the variable to prevent the spread of the corona virus, it was better to avoid touching eyes, mouth and nose too often to prevent corona transmission when using public transportation by $1.10 \%$.

\section{Bivariate Analysis}

In Table 2, from 166 respondents, it can be seen that the mean average attitude before intervention is 25.7 with standard deviation is 2.4 and standard error is 0.18 . Meanwhile, the mean avarage of attitude after being given intervention is 26.3 with standard deviation is 2.1 and standard error is 0.17 .

Table 2. Differences in Attitudes among Health Students Before and After Health Protocol Interventions

\begin{tabular}{lcccccc}
\hline Variable & N & Mean & SD & SE & Paired Difference & P.Value \\
\hline Attitude & & & & & & \\
Before the Intervention & 166 & 25,7 & 2,4 & 0,18 & $-2,41$ & 0,017 \\
After Intervention & 166 & 26,3 & 2,1 & 0,17 & & \\
\hline
\end{tabular}

In the statistical test, the p-value is 0.017 which states that there is a significant difference between the attitudes before and after the intervention.

\section{DISCUSSION}

From this research there was increase in the attitudes of health students in carrying out health protocols to prevent Covid-19 after being given health promotion interventions. Research by Peng et al., (2020) which stated that positive attitude in the prevention of Covid-19 in Chinese students were influenced by good knowledge about Covid19. Supported by the research of Usman, Budi, \& Nur Adkhana Sari (2020) which stated that the variable of good attitudes in health students in preventing Covid-19 in Indonesia is 206 (46.39\%), and research in India stated that medical students had different attitude both in the prevention of Covid19 Roy, Tripathy, Kumar, \& Sharma, (2020), as well as research in Pakistan which stated that the good attitude of students in preventing Covid-19 (Salman et al., 2020).

Allport (1935) stated that attitude is an individual closed response that involves the opinions and emotions of the individual (agree-disagree, happy-unhappy, good-bad), to certain stimuli or objects. Attitudes are often obtained from those closest to you and from your own experiences. Atti- tude causes a person to stay away or get closer to other objects or people. Positive attitude in health values do not necessarily manifest themselves into concrete actions, this is influenced by the current situation, other people's experiences, mount of the own person's experience, the values in that person's life that become his guide in carrying out social life. There has been increase in attitudes among health students before and after intervention, namely health promotion in carrying out health protocols to prevent Covid-19 which is shown in the form of wearing mask every time you leave the house, covering mouth with tissue or inside of elbow when coughing or sneezing, washing hands using soap or alcohol-based hand washing, avoiding frequent touching eyes, mouth and nose, bathing and changing clothes after activities outside the, limiting guests who will visit the house, if someone fever, cough and difficulty breathing immediately take medication and health checks. This increase in the attitude of health students occurred not only because of the increase in knowledge about Covid-19 prevention after intervention, but also because of the current situation where the increase in the number of Covid19 sufferers continues to increase, and their sense of responsibility as health workers will encourage to show a good attitude in preventing Covid-19. 


\section{CONCLUSION}

The number of samples in this research was 166 respondents, where the respondents were all active health students.

The frequency distribution of the attitude variable had an overall increase before and after the intervention, while the largest increase occurred in the variable avoiding contact with family and people at home before bathing or changing clothes after doing activities outside the house, which was 3.62\%. While the lowest increase in attitude variables was in the variable to prevent the spread of the corona virus, it was better to avoid touching eyes, mouth and nose too often to prevent corona transmission when using public transportation was $1.10 \%$. In the statistical test, the p-value was 0.017 which stated that there was significant difference between the attitudes before and after the intervention.

\section{SUGGESTION}

After the health promotion regarding the prevention and control of Covid-19 was given, it was hoped that health students will be able to practice health protocols such as wearing mask, washing hands with soap, carrying out etiquette coughing/ sneezing, bathing and changing clothes after activities outside the house, keeping distance from other people, avoiding frequent touching eyes, mouth and nose, checking their health if they feel fever. These all are in order to make them and their family can stay protected from Covid-19 and they can become example for the surrounding community in implementing health protocols.

\section{REFFERENCE}

Allport, G. W. (1935). 1. Attitudes. 1.

BNPB. (2020). Pedoman Perubahan Perilaku Penanganan COVID-19. Satgas Covid19, 60. Retrieved from https://covid19.go.id/storage/app/media/Materi Edukasi/Pedoman Perubahan Perilaku 18102020. pdf\%0Ahttps://covid19.go.id/p/protokol/pedomanperubahan-perilaku-penanganan-covid-19

CDC. (2020). Real-Time RT-PCR diagnostic panel. Centers for Disease Control and Prevention, CDC-006-00, 1-80. Retrieved from https://www.fda.gov/media/ 134922/download

Driposwana Putra, I., Malfasari, E., Yanti, N., Erlin, F., Hasana, U., Harahap, A. S., \& Hendra, D. (2021). Tingkat Kepatuhan Mahasiswa Kesehatan Dalam Berprotokol Kesehatan Pasca Lebih Dari Satu Tahun Masa Pandemi Covid-19. Jurnal Keperawatan Jiwa (JKJ): Persatuan Perawat Nasional
Indonesia, 9(2), 429-434. Retrieved from https:// jurnal.unimus.ac.id/index.php/JKJ/article/view/7331

Gorbalenya, A. E., Baker, S. C., Baric, R. S., de Groot, R. J., Drosten, C., Gulyaeva, A. A., ... Ziebuhr, J. (2020). Severe acute respiratory syndrome-related coronavirus: The species and its viruses $-\mathrm{a}$ statement of the Coronavirus Research Group. BioRxiv. https://doi.org/10.1101/2020.02.07.937862.

Hulu, V. T., Pane, H. W., Zuhriyatun, T. F., Munthe, S. A., Salman, S. H., Sulfianti, ... Mustar. (2020). Promosi Kesehatan Masyarakat. In Yayasan Kita Menulis.

IMF, I. M. F. (2020). World Economic Outlook Update June 2020. World Economic Outlook, (2), 6

Kementerian Kesehatan RI. (2020). Pedoman Pencegahan dan Pengendalian Corona Virus deases (Covid-19). Kementrian Kesehatan, 5, 178. Retrieved from https://covid19.go.id/storage/app/media/Protokol/ RE V-05 Ped om an P 2 C O VID 19_13_Juli_2020.pdf.

Peng, Y., Pei, C., Zheng, Y., Wang, J., Zhang, K., Zheng, Z., \& Zhu, P. (2020). A cross-sectional survey of knowledge, attitude and practice associated with COVID-19 among undergraduate students in China. BMC Public Health, 20(1), 1-24. https://doi.org/ 10.1186/s12889-020-09392-z

Patel, A., Jernigan, D. B., Abdirizak, F., Abedi, G., Aggarwal, S., Albina, D., ... Yousef, A. (2020). Initial public health response and interim clinical guidance for the 2019 novel coronavirus outbreak - United States, December 31, 2019-February 4, 2020. American Journal of Transplantation, 20(3), 889895. https://doi.org/10.1111/ajt.15805.

Roy, D., Tripathy, S., Kumar, S., \& Sharma, N. (2020). Since January 2020 Elsevier has created a COVID19 resource centre with free information in English and Mandarin on the novel coronavirus COVID19. The COVID-19 resource centre is hosted on Elsevier Connect, the company's public news and information. (January).

Salman, M., Mustafa, Z. U., Asif, N., Zaidi, H. A., Hussain, K., Shehzadi, N., ... Saleem, Z. (2020). Knowledge, attitude and preventive practices related to COVID19: a cross-sectional research in two Pakistani university populations. Drugs and Therapy Perspectives, 36(7), 319-325. https://doi.org/ 10.1007/s40267-020-00737-7

Syadidurrahmah, F., Muntahaya, F., Islamiyah, S. Z., Fitriani, T. A., \& Nisa, H. (2020). Perilaku Physical Distancing Mahasiswa UIN Syarif Hidayatullah Jakarta pada Masa Pandemi COVID-19. Perilaku Dan Promosi Kesehatan: Indonesian Journal of Health Promotion and Behavior, 2(1), 29. https:// doi.org/10.47034/ppk.v2i1.4004

Tim Kerja Kementrian Dalam Negeri. (2020). Pedoman Umum Menghadapi Pandemi Covid-19. Journal of Chemical Information and Modeling, 53(9), 16891699. 
Usman, S., Budi, S., \& Nur Adkhana Sari, D. (2020). Pengetahuan Dan Sikap Mahasiswa Kesehatan Tentang Pencegahan Covid-19 Di Indonesia. / Jurnal Ilmu Keperawatan Dan Kebidanan, 11(2), 410-414. Retrieved from Pengetahuan Dan Sikap
Mahasiswa Kesehatan Tentang Pencegahan Covid19 Di Indonesia.

WHO. (2020). termasuk penjangkauan dan kampanye, dalam konteks pandemi COVID-19 Panduan interim. 